\title{
Use of andiroba oil to control Anastrepha fraterculus (Diptera: Tephritidae) in different fruit hosts
}

\author{
Uso de aceite de andiroba para controlar Anastrepha fraterculus (Diptera: Tephritidae) \\ en diferentes hospedadores de frutas
}

\author{
CLEITON LUIZ WILLE'; JOATAN MACHADO DA ROSA²; \\ PAULO EDUARDO WILLE ${ }^{3}$; DAHISE BRILINGER ${ }^{4}$; CLÁUDIO ROBERTO \\ FRANCO $^{5}$; PEDRO BOFF ${ }^{6}$; PAULO ANTÔNIO DE SOUZA GONÇALVES ${ }^{7}$; \\ MARI INÊS CARISSIMI BOFF ${ }^{8}$
}

\begin{abstract}
${ }^{1}$ Agronomist. Santa Catarina State University, Department of agronomy, Lages, Santa Catarina 88520-000, Brazil, cleitonwille@gmail.com, https://orcid. org/0000-0002-0097-7394. ${ }^{2} \mathrm{Ph}$. D. Federal University of Paraná, Biological Sciences Sector, Centro Politécnico, Curitiba, Paraná, 81531-980, Brazil, joatanmachado@ufpr.br, https://orcid.org/0000-0002-1680-7525. ${ }^{3}$ M. Sc. Santa Catarina State University, Department of agronomy, Lages, Santa Catarina 88520-000, Brazil, pauloewille@gmail.com, https://orcid.org/0000-0002-5458-6102. ${ }^{4}$ M. Sc. Santa Catarina State University, Department of agronomy, Lages, Santa Catarina 88520-000, Brazil, dahise_b@hotmail.com, https://orcid.org/0000-0001-8419-0582. ${ }^{5} \mathrm{Ph}$. D. and professor. Santa Catarina State University, Department of agronomy, Lages, Santa Catarina 88520-000, Brazil, claudio.franco@udesc.br, https://orcid.org/0000-0001-7944-0671. ${ }^{6}$ Ph. D. Estação Experimental de Lages, Empresa de Pesquisa Agropecuária e Extensão Rural de Santa Catarina, Lages, Santa Catarina, 88502-970, Brazil, boff.pedro@yahoo. com. $b r$, https://orcid.org/0000-0002-9041-5503. ${ }^{7}$ Ph. D. Estação Experimental de Ituporanga, Empresa de Pesquisa Agropecuária e Extensão Rural de Santa Catarina, Ituporanga, Santa Catarina, 88400-000, Brazil,pasg@epagri.sc.gov.br, https://orcid.org/0000-0002-4480-9499. ${ }^{8}$ Ph. D. and professor. Santa Catarina State University, Department of agronomy, Lages, Santa Catarina 88520-000, Brazil, Mari.boff@udesc.br, https://orcid.org/0000-0003-1700-8837.
\end{abstract}

\section{Corresponding author}

Cleiton Luiz Wille. Agronomist. Santa Catarina State University, Department of agronomy, Lages, Santa Catarina 88520-000, Brazil, cleitonwille@gmail.com, https://orcid.org/00000002-0097-7394.

\section{Suggested citation}

WILLE, C. L.; ROSA, J. M.; WILLE, P. E.; BRILINGER, D.; FRANCO, C. R.; BOFF, P.; GONÇALVES, P. A. S.; BOFF, M. I. C. 2021. Use of andiroba oil to control Anastrepha fraterculus (Diptera: Tephritidae) in different fruit hosts. Revista Colombiana de Entomología 47 (1): e7698. https://doi.org/10.25100/socolen. v47i1.7698

Received: 10-Oct-2018

Accepted: 17-Feb-2020

Published: 09-Abr-2021

Revista Colombiana de Entomología ISSN (Print): 0120-0488

ISSN (On Line): 2665-4385

$\mathrm{https}$ //revistacolombianaentomologia.univalle.edu.co

Open access

(c) (i) () B B-NC-SA 4.0

Parsor/icenses/by-nc-sa/4.0/deed.es Publishers: Sociedad Colombiana de Entomología
SOCOLEN (Bogotá, D. C., Colombia) https://www.socolen.org.co

Universidad del Valle (Cali, Colombia)

https://www.univalle.edu.co

(C) 2021 Sociedad Colombiana de Entomología - SOCOLEN y Universidad del Valle - Univalle
Abstract: Control of Anastrepha fraterculus (Diptera: Tephritidae) is usually accomplished with synthetic insecticides, which can be a problem considering the exportation of fruits. This study aimed to evaluate mortality and offspring effects on A. fraterculus using peach, strawberry guava and apple fruits treated with andiroba (Carapa guianensis) oil. Higher mortality rate was observed when compared to control on strawberry guava and apple fruits treated with andiroba oil $(18.4 \%$ and $35.0 \%$ points more than the control). The mean number of pupae observed in the offspring was inferior to the control on strawberry guava and apple fruits treated with andiroba oil (100\% control) and, on peach fruits $(68.3 \%$ fewer pupae). Andiroba oil shows promising results as an alternative product to control $A$. fraterculus. Studies are still needed especially considering the effectiveness of andiroba oil under field conditions.

Keywords: Fruit flies, extracts, andiroba oil, alternative control.

Resumen: El control de Anastrepha fraterculus (Diptera: Tephritidae) generalmente se realiza con insecticidas sintéticos, lo que puede ser un problema si se considera exportar frutas. Este estudio tuvo como objetivo evaluar la mortalidad y el efecto de la descendencia en $A$. fraterculus en frutas de duraznos, guayabos peruanos y manzanas tratadas con aceite de andiroba (Carapa guianensis). Se observó una mayor tasa de mortalidad en comparación con el control para las frutas de guayabo peruano y manzana tratadas con aceite de andiroba (incremento del $18,4 \%$ y $35,0 \%$ puntos más que el control). El número medio de pupas observado en la descendencia fue inferior al control de guayabos peruanos y frutas de manzana tratadas con aceite de andiroba (control $100 \%$ ) y en frutas de durazno (68,3 \% menos pupas). El aceite de andiroba muestra resultados prometedores como un producto alternativo para controlar $A$. fraterculus. Son necesarios más estudios, en especial al considerar la efectividad del aceite de andiroba en condiciones de campo.

Palabras clave: Moscas de la fruta, extractos, aceite de andiroba, control alternativo.

\section{Introduction}

One of the main pests of fruit crops in Brazil is the South American fruit fly Anastrepha fraterculus Wiedemann, 1830 (Diptera: Tephritidae) which can cause damage in more than 115 fruit species (Zucchi and Moraes 2008). The predominant method to control $A$. fraterculus is the application of synthetic insecticides which may leave residues on fruits. This condition can be a major problem for exportation since many importing countries input strict limits on the amount of residue allowed (Handford et al. 2015).

The scientific literature suggests the use of botanical insecticides as alternatives to control pests. These products are becoming increasingly popular since some 
countries simplified their commercial registration (Isman 2015). Botanical insecticides have some advantages over synthetic insecticides as they are generally rapidly degraded in the environment and have a low production cost (Isman 2006).

The andiroba tree (Carapa guianensis Aubl., 1775) (Meliaceae) oil extracted from its seeds is one of the botanicals that has been proven to be effective to control some insects (Sarria et al. 2011; Prophiro et al. 2012). Besides, andiroba oil when administered to pregnant rats showed no toxicity to fetuses (Costa-Silva et al. 2007). No mutagenic, hemotoxic or genotoxic effect was also observed in another study with rats (Milhomem-Paixão et al. 2016). Although more studies need to be carried to access its toxicity in humans, andiroba oil seems to be an alternative and a safe product to be used instead of synthetic insecticides.

The goal of this study was to identify whether the deleterious effect found in other insects can also be observed in $A$. fraterculus in peach, apple and strawberry guava fruits treated with andiroba oil under laboratory conditions.

\section{Materials and methods}

The experiment was carried out at the laboratory of Santa $\mathrm{Ca}$ tarina State University (UDESC) $\left(-27.7922^{\circ} \mathrm{S} 50.3050^{\circ} \mathrm{W}\right)$ from January to July 2016. Peach (Prunus persica L. 'Chimarrita') (Rosaceae), strawberry guava (Psidium cattleianum Sabine var. Cattleyanum) (Myrtaceae) and apple (Malus domestica Borkh 'Fuji') (Rosaceae) fruits were previously bagged from trees of the campus to prevent field infestation. Peach and strawberry guava fruits were harvested when they reached $10^{\circ} \mathrm{Bx}$ while apples were harvested at the starch-iodine index of 4 using a 1 to 5 scale in which 1 indicates the least and 5 the most starch to sugar conversion.

Andiroba oil (Carapa guianensis) was purchased pure and diluted in ethanol $70 \%$ at $25 \%(\mathrm{v} / \mathrm{v})$ concentration. Rearing of $A$. fraterculus followed the method adopted by Nunes et al. (2015).

The experiment was carried out in a completely randomized design ( 3 fruits species x 1 botanical substances and 1 control, 10 replicates). Each fruit was immersed for 30 seconds in andiroba oil or in $70 \%$ ethanol (control), which were constantly being stirred by a magnetic stirrer, and left to dry for $5 \mathrm{~min}$ on a paper towel. Ethanol was used as a control treatment, as it was also used to dilute andiroba oil.

Each fruit was transferred to containers $(750 \mathrm{ml})$ and afterwards two adult couples of $A$. fraterculus (15 to 20 days old) were released into each container for 48 hours and maintained in a climatized chamber $\left(25 \pm 2{ }^{\circ} \mathrm{C}\right.$ and $\mathrm{RH} 60$ $\pm 10 \%$ ). Adult mortality was assessed after this period. The fruits were then transferred to new containers containing vermiculite and returned to the chamber for a period of 20 days. The number of insects in offspring was quantified by sieving the vermiculite and counting the number of pupae.

Data were submitted to the SAS software 9.4 University Edition (SAS institute 2015). Analysis of variance (ANOVA) was performed using the GLIMMIX procedure. The data were transformed to better fit the residuals to a Gaussian distribution using Box-Cox. Homoscedasticity and fitness of the distribution to the model were verified by diagnostic plots. Fisher's LSD test was performed by using the \% MULT macro (Piepho 2012).

\section{Results}

Adult mortality evaluation. Mortality of $A$. fraterculus was significantly affected by the treatment applied to the fruits and the interaction Treatment*Fruit species $(\mathrm{P}<0.05)$ (Table 1$)$. Andiroba oil caused mortality of $35.0 \%$ points higher than the control in strawberry guava fruits and $18.4 \%$ points higher than the control in apple fruits. The insecticidal effect of the andiroba oil was much more pronounced on apples and strawberry guava than on peach fruits (Table 1).

Offspring evaluation. Offspring of $A$. fraterculus was significantly affected by the treatment applied to the fruits and the fruit species $(\mathrm{P}<0.05)$ (Table 2$)$. A reduction in the number of insects in offspring compared to the control was observed in peach and apple fruits treated with andiroba oil (68.3\% and $100 \%$ fewer pupae observed). No significant difference was observed on treated strawberry guava fruits, nevertheless, no pupae were obtained in fruits treated with andiroba oil. The effect of the andiroba oil was once again more pronounced on strawberry guava and apple fruits than on peach fruits (Table 2).

\section{Discussion}

The explanation of the different results found in peach compared to the other fruits might be due to the different epidermis. While peaches present hairy epidermis, apple and strawberry guava fruits present smooth and glabrous epidermis which allow volatiles to be more easily released. Grammatikopoulos and Manetas (1994) complement by reporting that leaves with trichomes enable greater retention of liquids and consequently reduce the process of volatilization.

The insecticidal effect of andiroba oil may be related to the presence of gedunin, a limonoid present in the Carapa genus (Ambrozin et al. 2006) that is a potential antifeedant (Mikolajczak et al. 1988). The lethal effect of andiroba oil was observed in several species such as: the yellow fever mosquito (Aedes spp.) (Prophiro et al. 2012); fall armyworm (Sarria et al. 2011); brown dog tick [Rhipicephalus sanguineus (Latreille, 1806)] (Roma et al. 2015); maize weevil (Sitophilus zeamais Motschulsky, 1885) (Santos et al. 2015); as well as in A. fraterculus using pears (Pyrus communis) as hosts (Nunes

Table 1. Mean ( \pm SE) adult mortality (\%) of Anastrepha fraterculus after $48 \mathrm{~h}$ of exposure to fruits treated with andiroba (Carapa guianensis) oil. Summarized ANOVA table for each fixed effect considered in the model.

\begin{tabular}{lcccc}
\hline \multirow{2}{*}{ Treatment } & \multicolumn{4}{c}{ Fruit species } \\
\cline { 2 - 5 } & $\begin{array}{c}\text { Strawberry } \\
\text { guava }\end{array}$ & \multicolumn{2}{c}{ Peach } & Apple \\
\hline $\begin{array}{l}\text { Andiroba oil } \\
\text { Ethanol 70 } \% \\
\text { (control) }\end{array}$ & $37.50 \pm 4.93 \mathrm{aA}$ & $5.00 \pm 3.25 \mathrm{aB}$ & $20.45 \pm 3.88 \mathrm{aA}$ \\
\hline \multicolumn{1}{c}{ Fixed effect } & Num DF & Den DF & F value & P-value \\
\hline Treatment (T) & 1 & 50 & 14.07 & 0.0004 \\
Fruit species (F) & $2.50 \pm 2.81 \mathrm{bA}$ & $15.00 \pm 4.59 \mathrm{aA}$ & $2.08 \pm 2.69 \mathrm{bA}$ \\
Interaction T*F & 2 & 50 & 1.17 & 0.3174 \\
\hline
\end{tabular}

${ }^{1}$ Means followed by same lowercase letters among treatment in each fruit species and uppercases letters among fruit species in each treatment do not differ significantly by the Fisher's LSD test $(\mathrm{P}>0.05)$. 
Table 2. Mean ( \pm SE) number of pupae observed in the second generation following a $48 \mathrm{~h}$ exposure of fruits treated with andiroba (Carapa guianensis) oil to Anastrepha fraterculus adults. Summarized ANOVA table for each fixed effect considered in the model.

\begin{tabular}{lcccc}
\hline \multirow{2}{*}{ Treatment } & \multicolumn{4}{c}{ Fruit species } \\
\cline { 2 - 5 } & $\begin{array}{c}\text { Strawberry } \\
\text { guava }\end{array}$ & Peach & Apple \\
\hline Andiroba oil & $0.00 \pm 0.00 \mathrm{aA}$ & $7.00 \pm 3.56 \mathrm{aB}$ & $0.00 \pm 0.00 \mathrm{aA}$ \\
$\begin{array}{l}\text { Ethanol } 70 \% \\
\text { (control) }\end{array}$ & $1.40 \pm 1.38 \mathrm{aA}$ & $\begin{array}{c}22.10 \pm 5.11 \\
\mathrm{bB}\end{array}$ & $4.92 \pm 1.91 \mathrm{bB}$ \\
\hline \multicolumn{1}{c}{ Fixed effect } & Num DF & Den DF & F value & P-value \\
\hline Treatment (T) & 1 & 50 & 23.21 & $<0.0001$ \\
Fruit species (F) & 2 & 50 & 8.16 & 0.0008 \\
Interaction $\mathrm{T} * \mathrm{~F}$ & 2 & 50 & 1.41 & 0.2526 \\
\hline
\end{tabular}

${ }^{1}$ Means followed by same lowercase letters among treatments in each fruit species and uppercases letters among fruit species in each treatment substance do not differ significantly by the Fisher's LSD test $(\mathrm{P}>0.05)$.

et al. 2015). Additionally, the seeming repellent effect of the andiroba oil might be caused by its oily properties since lipids tend to provide a slipperier surface that discourages fruit fly oviposition (Hidayat et al. 2013). A similar repellent effect of andiroba oil was also observed by Rosa et al. (2013), which found that andiroba oil used in field traps significantly reduced the number of $A$. fraterculus adults captured.

\section{Conclusion and recommendations}

Andiroba oil caused adult mortality of $A$. fraterculus in treated strawberry guava and apple fruits as well as prevented its complete proliferation in the same fruits. The effect of the andiroba oil on peach fruits was only observed in the offspring as it reduced the number of pupae compared to the control by $68.3 \%$. It is recommended that other extraction methods should be tested since depending on the method adopted different concentrations of the constituents may predominate. More detailed studies are required to best access the effectiveness of the andiroba oil under field conditions.

\section{Acknowledgements}

To Conselho Nacional de Desenvolvimento Científico e Tecnológico $(\mathrm{CNPq})$, for scholarship to the first author and for an award for excellence in research (process number 304081/2015-9 and 307376/2017-6) and to Fundação de Amparo à Pesquisa e Inovação do Estado de Santa Catarina (FAPESC) for research financial support.

\section{Literature cited}

AMBROZIN, A. R. P.; LEITE, A. C.; BUENO, F. C.; VIEIRA, P. C.; FERNANDES, J. B.; BUENO, O. C.; SILVA, M. F. G. F.; PAGNOCCA, F. C.; HEBLING, M. J. A.; BACCI-Jr., M. 2006. Limonoids from andiroba oil and Cedrela fissilis and their insecticidal activity. Journal of the Brazilian Chemical Society 17 (3): 542-547. https://doi.org/10.1590/S0103-50532006000300017

COSTA-SILVA, J. H.; LYRA, M. M. A.; LIMA, C. R.; ARRUDA, V. M.; ARAÚJO, A. V.; RIBEIRO E RIBEIRO, A.; ARRUDA, A. C.; FRAGA, M. C. C. A.; LAFAYETTE, S. S. L.; WANDERLEY, A. G. 2007. A toxicological evaluation of the effect of $\mathrm{Ca}$ - rapa guianensis Aublet on pregnancy in Wistar rats. Journal of Ethnopharmacology 112 (1): 122-126. https://doi.org/10.1016/j. jep.2007.02.004

GRAMMATIKOPOULOS, G.; MANETAS, Y. 1994. Direct absorption of water by hairy leaves of Phlomis fruticosa and its contribution to drought avoidance. Canadian Journal of Botany 72 (12): 1805-1811. https://doi.org/10.1139/b94-222

GUAN, W.; LI, S.; YAN, R.; TANG, S.; QUAN, C. 2007. Comparison of essential oils of clove buds extracted with supercritical carbon dioxide and other three traditional extraction methods. Food Chemistry 101 (4): 1558-1564. https://doi.org/10.1016/j. foodchem.2006.04.009

HANDFORD, C. E.; ELLIOTT, C. T.; CAMPBELL, K. 2015. A review of the global pesticide legislation and the scale of challenge in reaching the global harmonization of food safety standards. Integrated Environmental Assessment and Management 11 (4): 525-536. https://doi.org/10.1002/ieam.1635

HIDAYAT, Y.; HEATHER, N.; HASSAN, E. 2013. Repellency and oviposition deterrence effects of plant essential and vegetable oils against female Queensland fruit fly Bactrocera tryoni (Froggatt) (Diptera: Tephritidae). Australian Journal of Entomology 52 (4): 379-386. https://doi.org/10.1111/aen.12040

ISMAN, M. B. 2006. Botanical insecticides, deterrents, and repellents in modern agriculture and an increasingly regulated world. Annual Review of Entomology 51: 45-66. https://doi. org/10.1146/annurev.ento.51.110104.151146

ISMAN, M. B. 2015. A renaissance for botanical insecticides? Pest Management Science 71 (12): 1587-1590. https://doi. org/10.1002/ps.4088

MIKOLAJCZAK, K. L.; WEISLEDER, D.; PARKANYI, L.; CLARDY, J. 1988. A limonoid antifeedant from seed of Carapa procera. Journal of Natural Products 51 (3): 606-610. https://doi. org/10.1021/np50057a033

MILHOMEM-PAIXÃO, S. S. R.; FASCINELI, M. L.; ROLL, M. M.; LONGO, J. P. F.; AZEVEDO, R. B.; PIECZARKA, J. C.; SALGADO, H. L. C.; SANTOS, A. S.; GRISOLIA, C. K. 2016. The lipidome, genotoxicity, hematotoxicity and antioxidant properties of andiroba oil from the Brazilian Amazon. Genetics and Molecular Biology 39 (2): 248-256. https://doi.org/10.1590/1678-4685-gmb-2015-0098

NUNES, M. Z.; BOFF, M. I. C.; SANTOS, R. S. S.; FRANCO, C. R.; ROSA, J. M. 2015. Control of the South American fruit fly in pear with natural-based products. Comunicata Scientiae 6 (3): 344-349. https://doi.org/10.14295/cs.v6i3.863

PIEPHO, H. P. 2012. A SAS macro for generating letter displays of pairwise mean comparisons. Communications in Biometry and Crop Science 7 (1): 4-13. http://agrobiol.sggw.waw.pl/ cbcs/articles/CBCS_7_1_2.pdf

PROPHIRO, J. S.; DA SILVA, M. A. N.; KANIS, L. A.; DA SILVA, B. M.; DUQUE-LUNA, J. E.; DA SILVA, O. S. 2012. Evaluation of time toxicity, residual effect, and growth-inhibiting property of Carapa guianensis and Copaifera sp. in Aedes aegypti. Parasitology Research 110 (2): 713-719. https://doi.org/10.1007/ s00436-011-2547-5

ROMA, G. C.; CAMARGO-MATHIAS, M. I.; NUNES, P. H.; REMÉDIO, R. N.; FARIA, A. U.; BECHARA, G. H. 2015. Effects of andiroba (Carapa guianensis) oil in ticks: Ultrastructural analysis of the synganglion of Rhipicephalus sanguineus (Latreille, 1806) (Acari: Ixodidae). Acta Tropica 141: 7-15. https:// doi.org/10.1016/j.actatropica.2014.06.018

ROSA, J. M.; BOFF, M. I. C.; GONÇALVES, P. A.; BOFF, P.; NUNES, M. Z. 2013. Andiroba oil (Carapa guianensis Aubl) in the capture of the fruit fly (Anastrepha fraterculus Wiedemann) in Feijoa (Acca sellowiana (Berg) Burret). Idesia 31 (3): 97-102. https://doi.org/10.4067/S0718-34292013000300013

SANTOS, A. C. V.; FERNANDES, C. C.; LOPES, L. M.; SOUSA, A. H. 2015. Use of plant oils from the southwestern Amazon for the control of maize weevil. Journal of Stored Products Research 63: 67-70. https://doi.org/10.1016/j.jspr.2015.07.002 
SARRIA, A. L. F.; SOARES, M. S.; MATOS, A. P.; FERNANDES, J. B.; VIEIRA, P. C.; SILVA, M. F. G. F. 2011. Effect of triterpenoids and limonoids isolated from Cabralea canjerana and Carapa guianensis (Meliaceae) against Spodoptera frugiperda (J. E Smith). Zeitschrift für Naturforschung 66 (5-6): 245-250. https://doi.org/10.1515/znc-2011-5-607

SAS Institute Inc. 2015. SAS/IML® 14.1 User's Guide. Cary, NC: SAS Institute Inc. https://support.sas.com/documentation/cdl/ en/imlsug/68152/PDF/default/imlsug.pdf

ZUCCHI, R. A.; MORAES, R. C. B. 2008. Fruit flies (Diptera: Tephritidae) in Brazil. Anastrepha species their host plants and parasitoids. Department of Entomology and Acarology ESALQ - University of São Paulo, Piracicaba, São Paulo, Brazil. Available in: http://www.lea.esalq.usp.br/anastrepha/ [Review date: 25 March 2018].

\section{Origin and funding}

This paper was written as a result of experiments conducted during a scholarship (CNPq-PIBIC) granted to the first author from 2015 to 2016. The results were orally presented in the $27^{\text {th }}$ scientific initiation seminar of CAV-UDESC.

\section{Author contribution}

The first author conducted the experiments, collected the data, performed statistical analyses and wrote the draft and final result of the paper. Second, third and fourth authors helped collect the data and provided suggestions to improve the final result of paper. Fifth, sixth, seventh and eighth authors supervised the conduction of experiments, provided mentorship, helped in the acquisition of the andiroba oil and funding for the project. 